\title{
Research and Application on Teaching Mode Based on New Media
}

\author{
Jia Keliang \\ School of Management Science and Engineering \\ Shandong University of Finance and Economics \\ Jinan, China \\ jiakeliang@sina.com
}

\begin{abstract}
In order to guide students rationally to use the new media platform, according to the characteristics of new media, the paper combined the constructivism and blended learning theory, then designed a blended teaching model based on the new media and built a new media teaching platform, finally designed the teaching implementation process for programming courses and applied it to teaching practice. The actual teaching effects show the teaching mode which combined the new media learning platform with the traditional classroom teaching process could improve the enthusiasm and initiative of students and get a better teaching effect.
\end{abstract}

Keywords—new media; teaching model; teaching platform

\section{INTRODUCTION}

New media is an emerging media form under the Internet and mobile Internet technology support system. With the popularity of portable electronic media such as smart phones and the rapid development of network services, mobile media became "the fifth media" after newspaper, radio, television, and network. College students who are willing to accept a fangle have become one of main audience of the new media. According to the thirty-fifth China Statistical Report on Internet Development released by CNNIC[1], as of December 2016 the mobile Internet users in Internet users accounted for up to $95.1 \%$, Internet users accounted for the highest proportion of high school, the students-to-netizen rate has actually risen $25.1 \%$, among them, college students were the main users and audience of mobile media. The new media of mobile phone was characterized by its sensitivity and rapidity, popularity, interaction and subjectivity. The new media had become the main way for college students to obtain information, transmit information and communicate with each other, had penetrated into all aspects of life of College Students, and had changed the way of life and study of College Students to some extent.

In recent years, it was often seen a negative report that college students played on mobile phones in the classroom. Some universities and colleges had taken restrictive measures from the perspective of management. The fundamental solution to the problem is not how to limit the use of mobile phone media, but is how to guide it in the light of its general trend, how to combine the new media and classroom teaching process under the guidance of Teachers and turn smart phone toys into learning tools. Teachers should conform to the modern college students' learning and living habits and change the traditional means of education and learning and then enhance the learning motivation of College Students.

Based on the constructivism and the blended learning theory, this paper combined the new media platform and its technology and programming courses closely and studied teaching content, teaching mode, teaching effect evaluation and so on, in order to guide students to make rational use of mobile phones and other new media and to improve their learning interest.

This paper was organized as follows, the research background was introduced in the first part, the related research were analyzed in the second part, then the new teaching model was designed and applied, finally the paper was concluded in the last part.

\section{RELATED RESEARCH}

In recent years, more and more colleges and universities had begun to apply the new media technology to teaching practice, used new media platform to establish virtual learning exchange space, explored teaching reform based on Internet plus and new media platform.

Sun Jing [2] studied the teaching mode innovation of program design course under Internet plus and put the mode into practice in the courses " $\mathrm{C}$ language programming" and "JAVA language programming ". ZHANG Li-na [3] built a mobile- internet based hybrid learning platform based on hybrid learning theory and mobile Internet. The proposed learning pattern had received good results in arousing students' learning interest when applied in practical teaching. He Xiuzhen [4] studied teaching reform of basic medical experiment technology based on smart phone and optimized the teaching quality. Yang Lin [5] has made remarkable achievements in reforming and Innovating College English teaching mode under the new media environment. Sun Ning [6] thought teachers should review and study on the construction of teaching resources under the background of new media in order to actively respond to and accurately grasp the challenges and opportunities brought about by the development of new media. YING Wenham [7] analyzed the current situation and main problems of teaching practice on software development 
courses and discussed about the teaching practice of software development courses in the new media era. Song Zhen [8] took the course of College Ideological and Political Theory as an example and reformed the teaching mode, course construction standards, and teacher-student interaction with the new media. The practices showed it could improve the effectiveness and pertinence of the course.

\section{THE DESIGN OF TEACHING MODEL BASED ON NEW MEDIA}

The new media era provides a new teaching model for the interaction between teachers and students. Compared with the traditional teacher-student interaction mode, the biggest feature of this model is the combination of "online" and "offline", it can diversify the interaction, further facilitate students to learn and ask questions and also make the teacher's guidance become more targeted.

In this paper, the teaching mode based on the new media would be used for the whole teaching process of the program design courses. Its specific contents include the design of mixed teaching model based on new media, the establishment of a teaching platform based on new media, the design and implementation of teaching process, the assessment system, as shown in Figure 1.

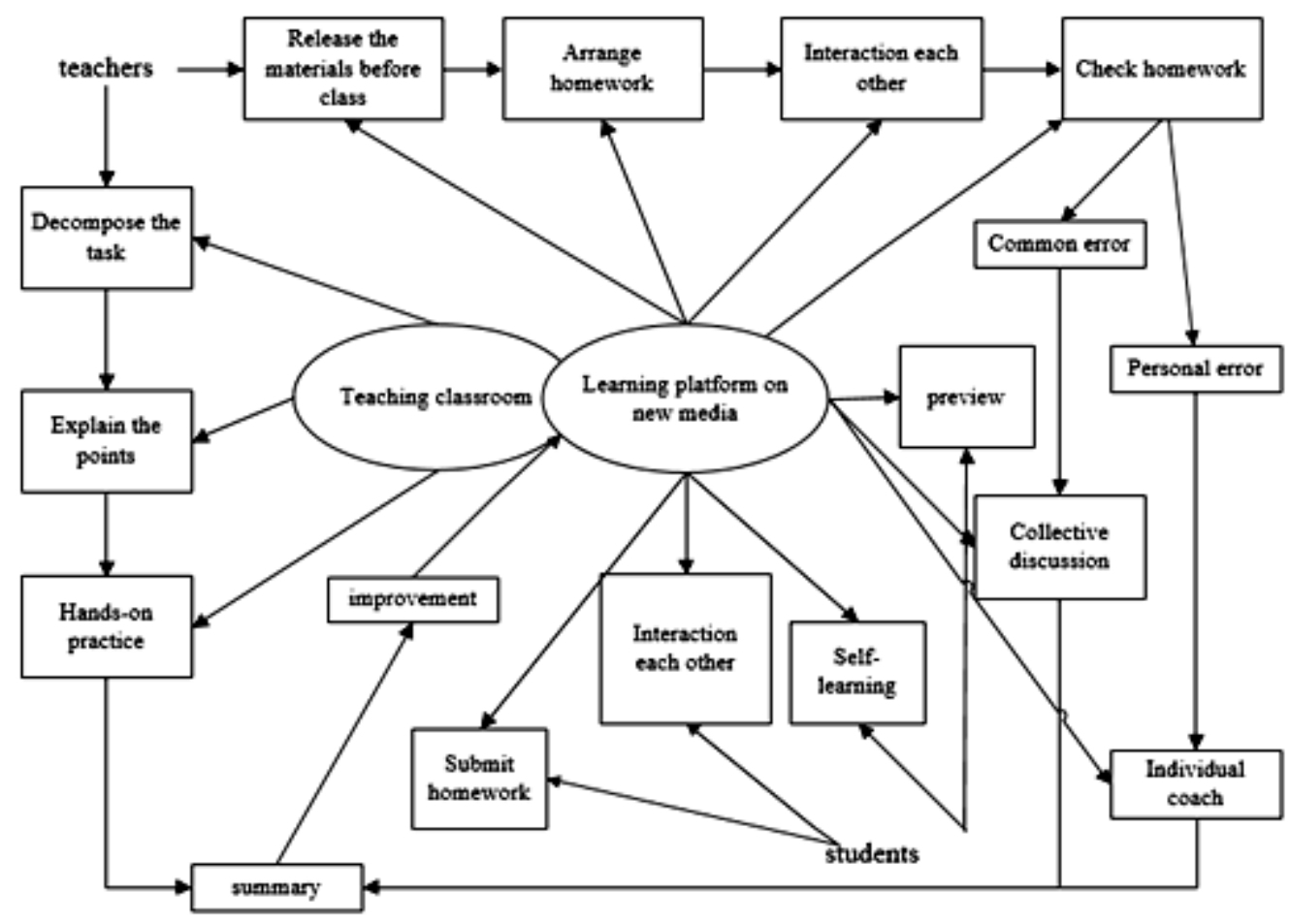

Fig. 1. Teaching mode based on new media

\section{A. The design of mixed teaching mode based on new media}

The paper introduced the new media platform to the teaching of programming courses and constructed a modern mixed teaching model. It could overcome the shortcomings of the traditional one-way teaching model, and could build an equal exchange and interaction platform between teachers and students, students and students. Teaching was not only the learning process of students, but also the process between teachers and students, students and students. With the new media technology, teachers could build an online multi functional and three-dimensional virtual communication platform. Teachers and students could share their perspectives, ideas, learning creativity and learning experience each other in the platform. Students could integrate and reorganize their knowledge structure in the interaction, and steadily enhance the enthusiasm and initiative of learning.
1) The mode combined personalized learning with cooperative learning

The opinion of constructivist learning theory is that students can help them complete the active construction of knowledge through cooperative learning and be encouraged to participate in group activities to enrich their learning experience [9]. According to the constructivism theory, this paper proposed a teaching model which combined the personalized learning with the cooperative learning. In the new media platform environment, students could easily communicate with each other, form study groups, build practice teams, exchange their learning experiences, and promote them to learn efficiently. Students could also download the learning materials according to their own learning progress to carry out independent personalized learning plan. For problems that were difficult to understand, students could communicate timely with teachers online in the 
platform. Relevant research shows students could accept easily online communication compared to face to face communication.

\section{2) The mode of combination of centralized learning and} scattered learning

The so-called blended learning is to combine the advantages of traditional learning methods and the advantages of network learning. In other words, the learning model could fully bring teachers into play leading role in guiding, inspiring and monitoring in teaching process, and at the same time fully reflect the initiative, enthusiasm and creativity of the students as the main body in the learning process. According to the blended learning theory, this paper putted forward a teaching model based on centralized learning and scattered learning. Classroom teaching focused on centralized learning. With the help of new media platform, students could make full use of their scattered time to learn and exchange learning experiences whenever and where they liked. The centralized learning in the classroom was beneficial for the students to master the complete framework of knowledge structure, but the scattered learning could make students focus on the local difficulties and key knowledge points. These two models were combined with each other and had complementary advantages each other.

\section{B. The Establishment of a Teaching Platform Based on New Media}

The paper used micro-blog, QQ, WeChat and other new media platform to establish a two-way interactive new media teaching platform. By using the platform, teachers could announce the teaching plan, courseware and other teaching materials, arrange/ collect/ correct the homework, dispel doubt with the answer, communicate with students. Students could download the teaching information, play the courseware and video online, submit the homework and experiment report and join the online forum through the platform. Teaching resources included course introduction, syllabus, teaching content design, courseware, video content, etc. Students could learn autonomously from the platform resources and discuss the encountered problems with teachers and other students. Teachers could review, supervise, and play a supervisory role in the process. Teachers could known the lack of classroom teaching trough two-way communication online with students and correct it. Teachers could get online feedback from students and facilitate timely online guidance to students. The establishment of two-way teaching mode could promote the interaction of information inside and outside the classroom and then further advance the reform of teaching mode.

\section{The Design and Implementation of Teaching Process}

According to the traditional classroom, firstly teachers decomposed the teaching task, explained the knowledge points, and then did hands-on practice and explained it. The new media learning platform included as follows.

1) Preparations before class. Teachers could release the teaching courseware, teaching video and other learning materials online prior to it being given in class. Students should download and preview all the teaching content before the class.
2) Cooperation and communication after class. Teachers could arrange homework and project tasks through the platform, so teachers can interaction with students and answer their questions; students could carry out their discussion and communication with the project team and download the learning materials through the platform. They could not only communicate which each other but also they could communicate with the teacher after class at all times and places.

3) Homework submission and inspection. Through the new media platform, students could submit and exhibit their homework. They could consult others' homework and the results, so they can be promoted and competed with each other; through the platform, teachers could check the homework, for common problems teachers could organize a collective discussion to resolve them, for individual errors teachers could give individual counseling.

4) Summary improvement phase. Through the new media platform, teachers could check students' homework, students discuss, comments, questions and so on statistical information, so they could grasp the situation if the students had mastered the knowledge, understand the characteristics of each student, know the main difficulties for students to grasp. And then teachers could focus on the difficult knowledge points and give someone targeted learning materials for individual guidance.

\section{The Assessment System}

The traditional examination mode of programming classes was to check if you had mastered the main points or not, written final examinations was the main examination way. This paper wanted to find a new comprehensive evaluation model of the programming classes at new media environment of program design courses in many ways, from mastering of knowledge, learning initiative, independent thinking, teamwork and other aspects of comprehensive evaluation. Through the new media platform, students could show their work and learning outcomes by individual or group model, they could also learn and evaluate from each other. The paper designed a new comprehensive evaluation model based on the study and work the students submitted, according to their learning activities and behavior in the new media platform, combining with the evaluation of teachers, students' self evaluation, group peer assessment and other assessment methods, and then constructed the comprehensive evaluation system of teaching effect of program design courses. All the evaluation indexes were weighted by a certain coefficient to form the comprehensive evaluation results of the final programming courses. This kind of evaluation could make the students to get a sense of achievement, to meet the needs of self cognition, and encourage students to explore new knowledge.

\section{E. Application and Practice}

In order to verify the effectiveness of the teaching model proposed in this paper, we carried out the teaching experiment with the students majoring in information management. Results show the mode can significantly raise the students' initiative in the discussion and the question compared with the traditional 
teaching mode. Classroom tests also show students could sturdily master the knowledge.

\section{CONCLUSION}

The new media blended teaching model combined the advantages of traditional teaching mode and new media, which could not only systematically impart the knowledge but also instantly interact between teachers and students. So its teaching effect is better. Specific performance is as follows:

- This new media teaching pattern can combine the advantages of different teaching modes, have complementary advantages. So students can not only grasp the main structure of the course through classroom teaching, but also can use the new media to learn key knowledge whenever and wherever.

- By using this new media platform, the paper explored a new interactive teaching mode for teacher-student, which was convenient for teachers and students to learn and interact with each other, and to establish an equal and harmonious relationship between teachers and students. The mode could also provide effective guidance for students' independent learning and good interactive environment, promote students' learning enthusiasm and learning initiative, so as to improve the students' autonomous learning ability and learning effect.

- Students could use this new media platforms for their study and discussion, complete coursework and project design together, which is helpful to cultivate students' cooperation ability and team spirit; Students could also use this new media platform to show their works and results, which is convenient for students to learn each other and is conducive to train their mutual learning and competitive consciousness.

\section{ACKNOWLEDGMENT}

This work is supported by Humanity and Social Science foundation of Education Ministry of China (No. 14YJC860011), Teaching Research Project of Shandong University of Finance and Economics (No. jy201516), and Excellent Course Optimized Project of Shandong University of Finance and Economics (Curriculum of the Fundamental of Programming).

\section{REFERENCE}

[1] China Statistical Report on Internet Development[EB/OL], http:// www. cnnic.net.cn/hlwfzyj/hlwxzbg/hlwtjbg/201701/P0201701233646726574 08.pdf(In Chinese)

[2] Sun Jing, Teaching mode innovation of program design course under Internet plus[J], FUJIAN COMPUTER, pp.51-53, Sep. 2016 (In Chinese).

[3] ZHANG Li-na, WANG Yue-chao, Application of Hybrid Learning Pattern Based on Mobile Internet in Higher Vocational Education[J], Journal of Guangzhou City Polytechnic, pp.91-94, Sep. 2016 (In Chinese).

[4] He Xiuzhen, Research on teaching reform of basic medical experiment technology based on smart phone[J], SCIENCE \& TECHNOLOGY INFORMATION, pp.153-154, Dec. 2015 (In Chinese).

[5] Yang Lin, College English teaching reform and innovation under the new media environment[J], Overseas English, pp.46-47, Sep. 2016 (In Chinese).

[6] Sun Ning, Sun Chen, Analysis of new media environment based on teaching resources construction[J], China Educational Technology, pp.91-95, July 2013 (In Chinese).

[7] YING Wen-hao, ZHU Shi, ZHOU Bei, CHANG Jin-yi, Discussion about the Teaching Practice of Software Development Courses in the New Media Era[J], Computer Knowledge and Technology, pp.38623864, June 2014 (In Chinese)

[8] Song Zhen, The Role of New Media in the Construction of Mobile Classroom -Taking the Course of College Ideological and Political Theory as an Example[J], JOURNAL OF NINGBO INSTITUTE OF EDUCATION, pp.7-10, Feb.2015 (In Chinese).

[9] He Kekang, New development of educational technology theory from Blending Learning[J], E-education Research, pp.1-6, March 2004 (In Chinese). 